\title{
PIDANA PENJARA DALAM PEMBAHARUAN \\ HUKUM PIDANA INDONESIA
}

\author{
Dede Kania \\ Fakultas Syari’ah dan Hukum UIN Sunan Gunung Djati Bandung \\ Email: dekan_0607@yahoo.co.id
}

\begin{abstract}
Imprisonment as the main criminal is the most threatened against offenders. Imprisonment in Indonesia criminal law as a legacy of colonial law enforcement. With the development of the concept of criminal theory form retributive to restorative sentencing, imprisonment and the implementation should be reviewed so that can be in accordance with human rights principles. This research examined the imprisonment in the Indonesian criminal law, customary criminal law, and Islamic Penal law, and also the concept of imprisonment renewal in the concept of Criminal Law Code of Indonesia, and then what is the punishment that is accordance with restorative justice theory that can protect the human rights of the convicted person, victims, and society.
\end{abstract}

Key Word: Imprisonment, human rights, restorative justice.

\begin{abstract}
Abstrak
Pidana penjara sebagai pidana pokok merupakan pidana yang paling banyak diancamkan terhadap pelaku kejahatan. Pemberlakuannya merupakan peninggalan hukum kolonial. Dengan perkembangan pemikiran mengenai konsep pemidanaan dari retributif ke restoratif, pelaksanaan pidana penjara pun harus dikaji ulang sehingga dalam penjatuhan maupun pelaksanaannya dapat sesuai dengan prinsip hak asasi manusia. Penelitian ini mengkaji penerapan pidana penjara dalam hukum pidana Indonesia, hukum pidana adat, dan hukum pidana Islam, serta konsep pembaharuan pidana penjara dalam RKUHP, kemudian bentuk pembaharuan pemidanaan apakah yang sesuai dengan teori restorative justice yang dapat melindungi hak asasi terpidana, korban, dan masyarakat.
\end{abstract}

Kata Kunci: Pidana penjara, hak asasi manusia, keadilan restoratif

\section{A. Pendahuluan}

Pemberlakuan pidana penjara di Indonesia merupakan hukum peninggalan Kolonial Belanda yang bersifat punitif dan represif. Sifat ini tidak lain karena dipengaruhi oleh ajaran pemidanaan yang berlaku pada saat itu, yaitu retributif. Menurut teori retributif, hukuman diberikan karena pelaku kejahatan harus 
menerima hukuman itu demi kesalahan. Hukuman menjadi retribusi yang adil bagi kerugian yang diakibatkan oleh perbuatannya. Dengan demikian, menurut teori ini hukuman layak diberikan kepada pelaku kejahatan atas pertimbangan bahwa pelaku kejahatan terbukti melakukan suatu kejahatan. Hukuman mengekspresikan bahwa pelaku kejahatan memiliki tanggung jawab atas pasal hukum yang dilanggarnya (Ibnu Artadi, 2006: 377).

Sistem peradilan pidana memang berhasil menuntut dan memenjara seseorang, tetapi di lain pihak ia telah gagal menciptakan kehidupan bermasyarakat yang aman. Seharusnya korban kejahatan diperlakukan secara bermartabat, kemudian antara pelaku dan korban atau keluarganya harus dirukunkan kembali (reconciled). Pelaku tidak hanya harus dipertanggungjawabkan tetapi juga wajib diintegrasikan kembali dalam masyarakat (Samuel C. Damren, 2002: 83).

Perkembangan pemidanaan yang bernilai keadilan restoratif di berbagai belahan dunia membuat perubahan signifikan terhadap pola pemidanaan retributif dengan lembaga penjara yang selama ini dianut. Di beberapa negara bahkan pidana penjara mulai ditinggalkan dan sebagai gantinya dikenalkan pidana kerja sosial, pidana pengawasan, dan pidana denda (Dwidja Priyatno, 2009: 49-53). Perubahan konsep pemidanaan ini di antaranya disebabkan akibat yang ditimbulkan oleh pidana penjara lebih besar efek negatifnya dan tidak membuktikan keberhasilannya dalam menekan angka kejahatan (Alison Liebling, 2006: 422).

Dalam rangka pembaharuan hukum pidana Indonesia, tentu saja pidana penjara sesuai Pasal 10 KUHP pun harus ditinjau kembali keberadaannya dalam konsep pemidanaan. Pembaharuan hukum pidana Indonesia haruslah memperhatikan hukum adat dan hukum Islam sebagai living law. Karena kedua sistem hukum living law Indonesia ini mengandung prinsip keadilan restoratif yang sangat tinggi dan telah teruji dalam menanggulangi kejahatan di masyarakat.

Penelitian ini mengkaji eksistensi pidana penjara dalam hukum pidana Indonesia dan menganalisis pola pemidanaan dalam Rancangan KUHP. 


\section{B. Metode Penelitian}

Penelitian ini adalah adalah yuridis normatif, yaitu penelitian terhadap kaidah hukum positif dan asas hukum yang dilakukan dengan cara melakukan evaluasi terhadap kaidah-kaidah hukum (peraturan perundang-undangan) yang relevan. Penelitian evaluasi terhadap hukum positif ini dilakukan dengan cara mengevaluasi segi kesesuaian antara satu kaidah hukum dengan kaidah hukum lainnya, atau dengan asas hukum yang diakui dalam praktek hukum yang ada, yang dilakukan dengan cara meneliti bahan pustaka atau data sekunder (Bagir Manan, 1999: 3-6). Penelitian didukung pula dengan metode penafsiran hukum, konstruksi hukum, filsafat hukum, sejarah hukum, dan perbandingan hukum. Teknik analisis data menggunakan penafsiran hukum sistematis, otentik, dan teleologis.

\section{Hasil Penelitian}

\section{Tentang Pidana Penjara}

Pidana penjara adalah suatu pidana berupa perampasan kemerdekaan atau kebebesan bergerak dari seorang terpidana dengan menempatkannya di lembaga pemasyarakatan (Dwidja Priyatno, 2009: 71-72) Pidana penjara ditetapkan secara resmi di Indonesia sejak berlakunya KUHP pada tanggal 1 Januari 1918, sebelumnya Indonesia hanya mengenal pidana badan dan pidana denda. Saat itu belum ada batasan yang tegas untuk membedakan antara pidana badan dan pidana penjara, karena dalam pelaksanaannya berupa nestapa yang dengan sengaja ditimpakan kepada seseorang yang yang melakukan pelanggaran hukum pidana.

Pidana penjara merupakan, jenis pidana yang paling banyak diancamkan kepada pelaku tindak pidana dalam Buku II KUHP. pidana penjara juga diancamkan terhadap tindak pidana yang diatur dalam undang-undang di luar KUHP, baik dirumuskan secara tunggal maupun secara kumulatif-alternatif dengan sanksi pidana lainnya (Dwidja Dwidja Priyatno, 2009: 72-77). Banyak sanksi pidana penjara diancamkan dalam KUHP maupun di luar KUHP dibandingkan dengan jenis pidana pokok lainnya, karena pidana penjara merupakan satu-satunya pidana pokok yang ada dalam KUHP yang 
memungkinkan diadakannya pembinaan secara terencana dan terarah terhadap terpidana, sedangkan jenis pidana pokok lainnya tidak memungkinkan adanya pembinaan dengan terhadap terpidana. Pelaksanaan pidana penjara pun kemudian mengalami perubahan mulai tahun 1964 dengan perubahan istilah pemenjaraan menjadi pemasyarakatan. Istilah penjara berubah menjadi lembaga pemasyarakatan (Suwarto, 2007: 166).

Kecendrungan yang ada sekarang, pidana penjara mengalami degradasi, karena mendapat banyak tantangan dan tekanan dari berbagai gerakan yang muncul di Eropa dan Amerika, sorotan keras terhadap pidana penjara tidak hanya diberikan oleh para pakar secara individual, melainkan juga oleh lembagalembaga internasional. Laporan kongres PBB kelima tahun 1975 mengenai Pencegahan Kejahatan dan Pembinaan Pelaku Kejahatan, ada kecenderungan untuk mengabaikan kemampuan lembaga-lembaga kejahatan. Pada perkembangan selanjutnya muncul gerakan abolisionis di Amerika yang menekankan reaksinya pada penghapusan sistem penjara dan gerakan abolisionis Eropa yang menekankan penolakannya terhadap sistem peradilan pidana secara keseluruhan, dengan sentralnya sistem kepenjaraan dengan memunculkan jenis pidana alternatif seperti denda dan kerja sosial (Dwidja Priyatno, 2009: 47-52).

Walaupun demikian, pidana penjara dianggap masih diperlukan untuk menghadapi berbagai kejahatan yang semakin banyak ragam dan modusnya. Herbert L. Packer mengemukakan bahwa: (1) sanksi pidana sangat diperlukan, kita tidak hidup sekarang maupun di masa yang tanpa pidana; (2) sanksi pidana merupakan alat atau sarana terbaik yang tersedia yang kita miliki untuk menghadapi bahaya-bahaya besar dan segera, serta untuk menghadapi ancamanancaman dari bahaya itu (Herbert L. Packer, 968: 364-365).

\section{Pengaturan Pidana Penjara}

\section{a. Pengaturan Pidana Penjara dalam KUHP}

Pasal 10 KUHP menetapkan jenis pidana yang diberlakukan di Indonesia terdiri atas:

a) Pidana pokok 
(1) Pidana mati

(2) Pidana penjara

(3) Kurungan

(4) Denda

(5) Pidana tutupan

b) Pidana tambahan

(1) Pencabutan hak-hak tertentu

(2) Perampasan barang-barang tertentu

(3) Pengumuman putusan hakim

Pasal 10 KUHP mengurut jenis pidana yang diancamkan kepada pelaku delik diurut dari yang terberat sampai teringan. Perbedaan pidana pokok dan pidana tambahan juga nampak jelas, bahwa: (1) pidana tambahan dapat ditambahkan pada pidana pokok dengan pengecualian perampasan barang-barang tertentu diserahkan kepada negara; (2) pidana tambahan bersifat fakultatif, artinya apabila hakim yakin mengenai tindak pidana dan kesalahan terdakwa, maka hakim tidak harus menjatuhkan pidana tambahan, kecuali untuk Pasal 250 bis dan Pasal 275 KUHP yang bersifat imperatif, yakni hakim harus menjatuhkan pidana pokok bila tindak pidana kesalahan terdakwa terbukti. Akan tetapi dalam penerapannya, hakim boleh memilih salah satu dari pidana pokok dan pidana tambahan.

Pidana penjara merupakan jenis sanksi yang paling banyak ditetapkan dalam perundang-undangan pidana selama ini. Secara tunggal, pidana penjara merupakan pidana yang paling banyak diancamkan, yaitu berjumlah 395 kejahatan ( \pm 67,29\%) (Dwidja Priyatno, 2009: 77). Data ini menunjukkan bahwa pidana penjara merupakan pidana yang paling banyak diancamkan dalam KUHP, walaupun demikian, tidak ditemukan alasan yang mendasari ditetapkannya pidana penjara sebagai salah satu jenis sanksi pidana untuk menanggulangi kejahatan. Selama ini tidak pernah dijelaskan alasan mengapa kejahatan harus ditanggulangi dengan ancaman pidana penjara, karena kebijakan kriminal selama ini menganggap wajar penggunaan pidana penjara dan sanksi hukum pidana terhadap 
terpidana. Begitu pun pada perundang-undangan di luar KUHP, pidana penjara masih merupakan ancaman pidana yang paling banyak diancamkan.

\section{b. Pengaturan Pidana Penjara dalam RKUHP}

Tujuan pidana menurut RKUHP mengalami perubahan sebagaimana dicantumkan dalam Pasal 54 ayat (1) bahwa pemidanaan bertujuan untuk:

1) Mencegah dilakukannya tindak pidana dengan mengegakkan norma hukum demi pengayoman masyarakat;

2) Memasyarakatkan terpidana dengan mengadakan pembinaan sehingga menjadi orang yang baik dan berguna;

3) Menyelesaikan konflik yang ditimbulkan oleh tindak pidana, memulihkan keseimbangan, dan mendatangkan rasa damai dalam masyarakat; dan

4) Membebaskan rasa bersalah pada terpidana.

Pasal 54 ayat (2) menyebutkan bahwa pemidanaan tidak dimaksudkan untuk menderitakan dan merendahkan martabat manusia. Sejalan dengan Pasal 54 yang sangat memperhatikan hak-hak terpidana, pada pedoman pemidanaan pun disebutkan bahwa pemidanaan sebagaimana tercantum dalam rumusan Pasal 55 ayat (1) wajib mempertimbangkan:

1) Kesalahan pembuat tindak pidana;

2) Motif dan tujuan melakukan tindak pidana;

3) Sikap batin pembuat tindak pidana;

4) Tindak pidana yang dilakukan apakah direncanakan atau tidak direncanakan;

5) Cara melakukan tindak pidana;

6) Sikap dan tindakan pembuat sesuadah melakukan tindak pidana;

7) Riwayat hidup, keadaan sosial, dan keadaan ekonomi pembuat tindak pidana;

8) Pengaruh pidana terhadap masa depan pembuat tindak pidana;

9) Pengaruh tindak pidana terhadap korban atau keluarga korban;

10) Pemafaan dari korban dan/atau keluarganya; dan/atau

11) Pandangan masyarakat terhadap tindak pidana yang dilakukan.

Kemudian dijelaskan pada Pasal 55 ayat (2) bahwa: 
Ringannya perbuatan, keadaan pribadi pembuat, atau keadaan pada waktu dilakukan perbuatan atau yang terjadi kemudian, dapat dijadikan dasar pertimbangan untuk tidak menjatuhkan pidana atau mengenakan tindakan dengan mempertimbangkan segi keadilan dan kemanusiaan.

Konsep RKUHP masih menjadikan pidana penjara sebagai salah satu pidana pokok yang diancamkan kepada pelaku kejahatan. Sebagaimana diatur dalam Pasal 65:

\section{Pasal 65}

(1) Pidana Pokok terdiri atas:

a. Pidana penjara;

b. Pidana tutupan;

c. Pidana pengawasan;

d. Pidana denda; dan

e. Pidana

(2) Urutan pidana sebagaimana dimaksud pada ayat (1) menentukan berat ringannya pidana

Penjelasan pelaksanaan pidana penjara tercantum pada Pasal 69-75. Pada Pasal 69 dijelaskan bahwa :

\section{Pasal 69}

(1) Pidana penjara dijatuhkan untuk seumur hidup atau untuk waktu tertentu.

(2) Pidana penjara untuk waktu tertentu dijatuhkan paling lama 15 (lima belas) tahun berturut-turut atau paling singkat 1 (satu) hari, kecuali ditentukan minimum khusus.

(3) Jika dapat dipilih antara pidana mati dan pidana penjara seumur hidup atau jika ada pemberatan pidana atas tindak pidana yang dijatuhi pidana penjara 15 (lima belas) tahun maka pidana penjara untuk waktu tertentu dapat dijatuhkan untuk waktu 20 (dua puluh) tahun berturut-turut.

(4) Dalam hal bagaimanapun pidana penjara untuk waktu tertentu tidak boleh dijatuhkan lenih dari 20 (dua puluh) tahun.

Dalam pokok Rancangan KUHP tidak lagi mengenal pidana kurungan, yang menurut pola KUHP biasanya diancamkan untuk tindak pidana “Pelanggaran”. Jenis pidana tambahan dan tindakan di dalam konsep RKUHP mengalami perluasan, diantaranya adalah dirumuskan secara eksplisit jenis pidana tambahan berupa “pemenuhan kewajiban adat”. Dirumuskannya jenis pidana adat, dimaksudkan untuk menampung jenis sanksi adat atau sanksi menurut hukum tidak tertulis. 


\section{c. Pengaturan Pidana Penjara dalam Hukum Adat}

Indonesia merupakan negara yang sangat kaya dengan keberagaman hukum adatnya. Dalam lapangan hukum pidana pun di beberapa daerah masih diakui berlakunya hukum pidana adat. Wajar kalau kemudian hukum pidana adat dijadikan sumber dalam pembentukan hukum pidana nasional. Eksistensi hukum pidana adat harus terus dikembangkan, karena hukum pidana adat merupakan hukum yang bersumber langsung dari masyarakat (living law), sehingga akan terus hidup dan tumbuh di masyarakat adat Indonesia (Otto Yudianto, 2012: 25).

Eksistensi hukum pidana adat tetap dipertahankan dalam hukum pidana nasional ke depan, terlihat dalam RKUHP. Konsep Pasal 2 menjelaskan bahwa hukum pidana adat akan tetap diakui oleh hukum nasional baik dalam bentuk ketentuan pidana maupun pemidanaan, sepanjang sesuai dengan nilai-nilai Pancasila dan/atau prinsip-prinsip hukum umum yang diakui oleh masyarakat bangsa-bangsa. Konsep pidana maupun penyelesaian dalam hukum pidana adat mempunyai ciri khas yang sangat mengedepankan nilai-nilai komunal. Begitu pun dalam bentuk pemidanaan, dalam hukum pidana adat mengedepankan sanksi yang bersifat moral, sosial, berupa pidana badan dan pidana denda, tidak menetapkan penjara sebagai salah satu bentuk pidana. Bentuk-bentuk sanksi dalam hukum pidana adat sangat memperhatikan kemanfaatan bentuk pemidanaan bagi masyarakat. pemidanaan dijatuhkan untuk mengembalikan keseimbangan kosmis religius yang telah ternoda akibat kejahatan yang dilakukan oleh pelaku pidana.

Delik pidana adat sendiri diartikan sebagai semua perbuatan perbuatan atau kejadian yang bertentangan dengan kepatutan, kerukunan, ketertiban, keamanan, rasa keadilan, dan kesadaran hukum masyarakat, baik akibat perbuatan seseorang maupun perbuatan penguasa. Dari pengertian ini diketahui bahwa dalam hukum adat, tidak dibedakan perbuatan melawan hukum yang dapat dipidana dan yang mempunyai akibat perdata.

Salah satu filosofi penyelesaian sengketa di masyarakat adat adalah keadilan, yaitu berupa keadilan komunal. Keadilan komunal adalah keadilan di mana tidak ada yang merasa dirugikan dengan keputusan yang diambil ketua atau 
tokoh adat dalam penyelesaian perkara adat. Keadilan ini sangat penting ditegakkan sebagai sendi dari tatanan kehidupan masyarakat adat. Harkat dan martabat masyarakat hukum adat, sangat ditentukan oleh tingkat sejauh mana nilai-nilai keadilan komunal diwujudkan. Semakin tinggi nilai keadilan komunal, maka semakin kuat dan mulia kedudukan masyarakat hukum adat tersebut (Syahrizal Abbas, 2011: 246).

Tradisi penyelesaian sengketa dalam masyarakat hukum adat cenderung menggunakan pola adat atau secara kekeluargaan. Pola ini diterapkan bukan hanya untuk sengketa perdata dan pidana. Penyelesaian sengketa dengan pola adat ini juga menghasilkan sanksi atau kompensasi terhadap pelanggar hukum adat. Sanksi yang diterapkan bisa berupa hukuman badan atau kompensasi harta benda, penerapannya tergantun pada jenis dan berat ringannya sengketa para pihak. Penyelesaian sengketa adat sendiri bertujuan untuk mewujudkan perdamaian secara komprehensif, yang tidak hanya ditujukan kepada pelaku delik dan korban saja, melainkan juga mewujudkan perdamaian bagi masyarakat adat secara keseluruhan(Syahrizal Abbas, 2011: 246-248).

Hukum adat sendiri ciptaan pikiran yang komunal magis religius atau komunal kosmis. Dengan alam pikiran pikiran yang bersifat kosmis, hukum adat menempatkan kehidupan manusia sebagai bagian dari alam, artinya kehidupan manusia berkaitan sangat erat dengan alam, apabila terjadi kegoncangan dalam kehidupan manusia pasti menyebabkan ketidakseimbangan kehidupan alam, kgoncangan alam pasti berakibat pada kehidupan manusia. Model pemikiran kosmis tersebut menimbulkan pandangan.

Hukum adat adalah hukum yang tidak tertulis yang tidak memiliki sistematika tertentu dalam mengkatagorikan perbuatan sebagai kejahatan atau pelanggaran. Semua perbuatan yang mengganggu keseimbangan masyarakat atau alam dipandang sebagai pelanggaran adat. Hukum pidana adat pun tidak menentukan secara jelas jenis atau sanksi pidana yang dapat diterapkan terhadap pelaku delik adat. Dari semua pidana adat yang masih berlaku di Indonesia, semuanya memberlakukan pidana mati dan denda. Pidana adat tidak mengenal pemenjaraan. Walaupun demikian beberapa ahli menyebutkan bahwa pemasungan 
secara hakikat hampir sama dengan pidana penjara, karena sama-sama merampas kemerdekaan dan kebebasan pelaku kejahatan. Demikian juga dalam pidana pembuangan atau pengusiran pelaku kejahatan, konsep ini bermakna dijauhkannya pelaku dan keluarga dari lingkungan adat, sehingga tidak mengganggu keseimbangan dalam masyarakat. Konsep hukum adat berangkat dari ide dasar perlindungan semata. Pemberian sanksi lebih didasarkan pada teori absolut atau retributif, yang melihat kesesuaian antara perbuatan pelaku dengan kerusakan yang ditimbulkannya. Sedangkan tujuan pemberiannya sendiri lebih pada konsep perlindungan kehidupan masyarakat (Otto Yudianto, 2012 : 26).

\section{d. Pengaturan Pidana Penjara dalam Hukum Islam}

Tindak pidana (jarimah) dalam hukum pidana Islam terbagi tiga macam, yaitu hudud, qishash, dan ta'zir (Umar al-Tamimi, 2013: 460-463). Tindak pidana hudud adalah tindak pidana yang diancam dengan hukuman hadd, yaitu hukuman yang telah ditentukan oleh syariat dan merupakan hak Allah. Berbeda dengan konsep pidana qishash dan diyat, konsep hudud adalah murni pidana yang ditetapkan al-Quran dan merupakan sesuatu yang baru di zaman Rasulullah saw.

Secara bahasa, hadd berarti pencegahan dan pintu, dikatakan demikian karena mencegah manusia untuk masuk atu melakukannya. Hadd juga diartikan hukuman yang bersih karena dengan hukuman tersebut mencegah seseorang melakukan kejahatan. Tindak Pidana hudud ini ada tujuh macam, yaitu :

1) Jarimah zina dipidana dengan pidana rajm;

2) Jarimah qadzaf (menuduh orang berzina) dipidana dengan pidana rajm;

3) Jarimah syurb al-khamr (meminum khamr/minuman keras);

4) Jarimah sariqah (pencurian) dipidana dengan pidana potong tangan;

5) Jarimah hirabah (perampokan/gangguan keamanan) dipidana dengan pidana salib atau pidana mati;

6) Jarimah riddah (murtad) dipidana dengan pidana mati;

7) Jarimah al-baghu (pemberontakan) dipidana dengan pidana salib atau pidana mati. 
Ditetapkannya bentuk-bentuk pidana tersebut harus dipahami sebagai usaha al-Quran untuk lebih menyederhanakan pemidanaan dan meringankan beban terpidana dengan tujuan untuk mencegah bercampurnya kebenaran dan kebatilan dalam masyarakat, sehingga masyarakat akan terlindungi dari berbagai kemungkinan perbuatan maksiat dan dosa.

Jarimah kedua adalah jarimah qishash dan diyat, yaitu jarimah yang diancam dengan qishash atau diyat. Ukuran penghukuman dalam qishash dan diyat sudah ditetapkan al-Quran dan Hadis Nabi, pertanggungjawabannya sendiri bersifat individual. Penetapan pidana ini berarti, bahwa pidana yang dijatuhkan tidak boleh terlalu melebihi atau kurang dari ukuran yang telah ditetapkan, melainkan harus seimbang tidak kurang dan tidak lebih. Pada qishash terdapat hak korban, apabila ia berkehendak memaafkan, maka terpidana akan terbebas dari pidana qishash.

Jarimah ketiga, yaitu jarimah ta'zir adalah jarimah yang diancam dengan hukuman ta'zir. Kata ta'zir diartikan dengan menolong, kata ta'zir juga diartikan memberi pengajaran (al-ta'dib). Sedangkan dalam istilah hukum pidana Islam, ta'zir adalah pidana yang bersifat mendidik yang tidak mengharuskan pelakunya dikenai hadd atau tidak pula harus membayar kifarat atau diyat. Ta'zir diartikan sebagai hukuman pendidikan atas dosa (tindak pidana) yang belum ditentukan hukumannya oleh syariat. Karena belum ditetapkan oleh syariat wewenang untuk menetapkannya diserahkan kepada penguasa (ulil amri). Syariat hanya menyebutkan macam-macam hukuman ta'zir dari yang paling ringan sampai yang paling berat namun tidak secara jelas menentukan jenis ta'zir untuk hukuman tertentu, dalam hal ini hakim diberi kebebasan untuk memilih hukuman mana yang sesuai.

Jenis pidana yang termasuk ta'zir antara lain pidana penjara, pemecatan, ganti kerugian, teguran, dan jenis pidana lain yang dipandang sesuai dengan pelanggaran yang dilakukan. Jenis pidana yang berkaitan dengan ta'zir ini diserahkan sepenuhnya kepada kesepakatan manusia. Jarimah ta'zir dapat dibagi tiga, yaitu: 
1) Jarimah hudud dan qishash diyat yang mengandung unsur syubhat atau tidak memenuhi syarat, namun hal itu sudah dianggap sebagai perbuatan maksiat seperti pencurian harta syirkah, pembunuhan ayah terhadap anaknya, dan pencurian yang bukan harta benda;

2) Jarimah ta'zir yang jenis jarimahnya ditentukan oleh nash, tetapi sanksinya oleh syariah diserahkan kepada penguasa, seperti sumpah palsu, saksi palsu, mengurangi timbangan, menipu, mengingkari janji, menghianati amanah, dan menghina agama.

3) Jarimah ta'zir dimana jenis jarimah dan sanksinya secara penuh menjadi wewenang penguasa demi terealisasinya kemaslahatan umat. Dalam hal ini unsur akhlak menjadi pertimbangan yang paling utama, misalnya pelanggaran terhadap peraturan lingkungan hidup, lalu lintas, dan pelanggaran terhadap pemerintah, dan lain-lain.

Dari jenis pemidanaan qishash-diyat, hudud, dan ta'zir diketahui bahwa konsep pemidanaan dalam hukum pidana Islam sebenarnya telah jauh menjangkau ke depan, karena tidak hanya mengenal sanksi dalam bentuk pidana atau straf, tetapi juga mengenal sanksi dalam bentuk tindakan (matregel), yang saat ini dikenal dengan bentuk sanksi double track system (Otto Yudianto, 2012: 22). Penjatuhan pidana dalam Islam sendiri sangat memperhatikan sisi kemaslahatan masyarakat, tidak hanya memperhatikan aspek legalitas belaka. Adapun tujuan hukum pidana Islam adalah untuk: (1) menegakkan keadilan; (2) membuat jera pelaku; (3) memberi pencegahan secara umum; (4) memperbaiki pelaku (Umar al-Tamimi, 2013: 471-472).

Hukum pidana Islam tidak mengenal pemenjaraan, karena konsep ini merupakan konsep yang lahir di dunia Barat. Pemidanaan dalam hukum pidana Islam bersifat segera dengan memaksimalkan perlindungan bagi pelaku pidana, korban, dan masyarakat lainnya. Pidana penjara hanya dapat diterima sepanjang pidana tersebut memberikan kemaslahatan dan kemanfaatan bagi masyarakat (Otto Yudianto, 2012: 24). 


\section{Analisis keberadaan Pidana Penjara dalam Pembaharuan Hukum}

\section{Pidana}

Pidana yang dijatuhkan kepada pelaku kejahatan merupakan sesuatu yang adil dalam berbagai perspektif teori pemidanaan (Gargi Roy, 2014: 95). Namun, harus dipertimbangkan pula sisi keadilan dan kemanfaatan bentuk pemidanaan yang akan dijatuhkan kepada pelaku kejahatan. Jangan sampai pemidanaan yang dijatuhkan melanggar hak asasi manusia si pelaku kejahatan itu sendiri.

Pidana penjara sebagai jenis pidana yang merampas hak kebebesan seseorang tentu saja melanggar hak asasi manusia, terutama apabila pidana penjara dijatuhkan seumur hidup, ini merupakan bentuk hukuman yang sangat tidak manusiawi (Esther Gumboh, 2011: 77). Pidana penjara terkadang harus dijalani seseorang yang divonis pidana mati, yang seringkali tanpa kejelasan kapan ia akan divonis. Harus diakui banyak hal negatif dari sistem pembinaan dalam pidana penjara, yang harus dialami narapidana diantaranya:

1) Secara sosiologis pemenjaraan menjadikan seseorang terpisah dari keluarganya. Apabila ia adalah kepala keluarga maka sejatinya ia mempunyai kewajiban memberi nafkah keluarganya, isteri dan anak-anaknya maupun orang lain yang sebelum ia dipenjara ia tanggung nafkahnya, selain itu tentu saja pemenuhan kebutuhan biologisnya pun menjadi terganggu;

2) Di penjara, sistem pembinaan ternyata kurang berjalan dengan baik, di LAPAS ditemukan kelompok-kelompok yang sering memeras kelompok lainnya, bertindak kasar dan berkelahi. Petugas LAPAS seringkali bertindak pilih kasih, dan LAPAS pun berfungsi menjadi tempat transfernya ilmu kejahatan sehingga timbul adagium bahwa LAPAS merupakan sekolah ilmu kejahatan (SIK) (Andrew Stevano Kokong, 2012: 53);

3) Sistem pemidanaan melalui pidana penjara menjadikan seorang narapidana terisolasi dari masyarakat dan keluarga, sehingga secara psikologis narapidana dapat mengalami stress dan penurunan kesehatan mental (Alison Liebling, 2006: 425);

4) Keluar dari penjara, masyarakat justru takut dan bahkan tidak mau menerimana kembali mantan narapidana, karena takut apabila mantan 
narapidana tersebut melakukan kejahatan kembali. Terjadi labelling mantan narapidana dengan sebutan penjahat, sehingga keluar dari LAPAS ia sangat kesulitan mendapat pekerjaan untuk menghidupi diri dan keluarganya, sehingga tidak sedikit narapidana yang akhirnya melakukan kejahatan kembali (residivist).

Perkembangan teori pidana dan pemidanaan dari retributif kepada keadilan restoratif, yang menghendaki adanya perlakuan yang lebih manusiawi kepada pelaku kejahatan, dan melindungi hak-hak korban maupun keluarga dan masyarakat. Pada proses penyelesaian kasus pidana menurut restorative justice melalui musyawarah untuk mufakat, di mana masing-masing pihak mempunyai kedudukan yang sama dan tidak ada yang mendominasi (John Braithwaite, 2002: 565), adapun fokus penyelesaiannya terletak pada mediasi dan pemulihan hubungan antara pelaku kejahatan dan korban (Edward J. Gumz dan Cynthia L. Grant, 2009: 121). Penyelesaian perkara dengan restorative justice bertujuan menghasilkan keberhasilan dalam penegakan hukum dengan melibatkan seluruh pihak yang terlibat dalam suatu kejahatan, yaitu pelaku, korban, anggota keluarga dari pelaku dan korban, serta masyarakat. Penyelesaian kasus pidana dapat lebih adil dan lebih efektif karena semua pihak terlibat aktif (Okwendi Joseph Solomon dan Richard Nwankwoala, 2014: 128). Pelaku kejahatan harus memperbaiki akibat yang ditimbulkan oleh kejahatan yang dilakukannya, korban secara fisik dan psikis mendapat pemulihan dalam bentuk ganti rugi dan mengurangi bahkan penyembuhan rasa takut atau trauma, masyarakat mengambil bagian dalam pemulihan akibat negatif dengan cara menerima kembali pelaku kejahatan dan memberi pengajaran kepada anggota masyarakat lainnya supaya tidak melakukan kejahatan lainnya.

Apabila dilihat dari kajian restorative justice di atas, maka tujuan pemidanaan dalam RKUHP sebagaimana dicantumkan dalam Pasal 54 ayat (1) huruf c, yaitu untuk, "menyelesaikan konflik yang timbul oleh tindak pidana, memulihkan keseimbangan, dan mendatangkan rasa damai dalam masyarakat”, adalah sesuai dengan teori restorative justice yang menitikberatkan penyelesaian perkara pada pemulihan keseimbangan dan rasa damai di masyarakat. Sebenarnya, 
bila dilihat dari perspektif hukum adat, maka masyarakat adat Indonesia sudah sejak lama menggunakan prinsip ini. Karenanya, rumusan Pasal 54 ayat (1) huruf c RKUHP sejalan dengan dengan teori keseimbangan yang bersumber dari adat bangsa Indonesia (Siti Nurjanah, 2011).

Pidana penjara dalam RKUHP dapat dijatuhkan untuk (1) seumur hidup atau untuk waktu tertentu, (2) paling lama 15 tahun berturut-turut atau paling singkat 1 hari kecuali ditentukan minimum khusus (Pasal 69). Kemudian diatur pembatasan pidana penjara untuk waktu tertentu tidak boleh lebih dari 20 tahun. RKUHP juga merumuskan aturan bahwa terpidana mati yang telah menjalani pidana paling kurang 17 tahun dapat diberikan pembebasan bersyarat apabila terpidana berkelakuan baik (Pasal 70).

Pasal 71 merumuskan bahwa pidana penjara bahkan sejauh mungkin tidak dijatuhkan apabila: (1) terdakwa berusia kurang dari 18 tahun atau lebih dari 70 tahun; terdakwa baru pertama kali melakukan tindak pidana; (3) kerugian dan penderitaan korban tidak terlalu besar; (4) terdakwa telah membayar ganti kerugian kepada korban; (5) terdakwa tidak mengetahui bahwa tindak pidana yang dilakukan akan menimbulkan kerugian yang besar; (6) tindak pidana terjadi karena hasutan yang sangat kuat dari orang lain; (7) korban tindak pidana mendorong terjadinya tindak pidana tersebut; (8) tindak pidana tersebut merupakan akibat dari suatu keadaan yang tidak mungkin terulang lagi; (9) kepribadian dan perilaku terdakwa meyakinkan bahwa ia tidak akan melakukan tindak pidana yang lain; (10) pidana penjara akan menimbulkan penderitaan yang besar bagi terdakwa atau keluarganya; (11) pembinaan yang non-institusional diperkirakan akan cukup berhasil untuk diri terdakwa; (12) penjatuhan pidana yang lebih ringan tidak akan mengurangi sifat beratnya tindak pidana yang dilakukan terdakwa; (13) tindak pidana terjadi di kalangan keluarga; (14) terjadi karena kealpaan.

Perumusan peniadaan pidana penjara atau perubahan bentuk pidana dari pidana penjara kepada bentuk pidana atau tindakan dalam Pasal 71 RKUHP di atas merupakan bentuk perlindungan hak terpidana dan keluarganya. Dengan demikian RKUHP berupaya membentuk hukum pidana yang melindungi hak-hak 
terpidana. Walaupun demikian, pidana penjara tetap tidak memberikan porsi yang besar bagi perlindungan korban dan masyarakat. Sebagai bentuk perlindungan korban RKUHP merumuskan pada Pasal 99 ayat (1) bahwa: "Dalam putusan hakim dapat ditetapkan kewajiban terpidana untuk melaksanakan pembayaran ganti kerugian kepada korban atau ahli warisnya”. Kemudian Pasal 100 RKUHP merumuskan tentang kewajiban adat yang harus dilaksanakan oleh terpidana. Penggunaan pidana adat dalam pemidanaan pada Pasal 100 ini sesuai dengan rumusan dalam Pasal 2 ayat (2).

Perumusan kata “dapat” dalam Pasal 99 ayat (1) menunjukkan bahwa penetapan ganti kerugian bukanlah dalam kewajiban pidana, yang berarti boleh dilakukan atau tidak. Seharusnya apabila kejahatan yang dilakukan terpidana memang menimbulkan kerugian kepada korban atau ahli warisnya maka terpidana wajib memberikan ganti rugi kepada korban atau ahli warisnya sesuai dengan kerugian yang ditimbulkan oleh tindak pidana yang dilakukannya. Hal ini sesuai dengan rumusan pembayaran ganti kerugian dalam hukum pidana Islam atau dalam hukum pidana adat.

Dalam rangka perubahan ide pemidanaan ini, selain pidana penjara, dalam RKUHP juga dirumuskan jenis pemidanaan baru berupa pidana pidana pengawasan, pidana denda, dan pidana kerja sosial (Pasal 65 ayat (1) RKUHP), sedangkan pidana mati diubah menjadi pidana pokok yang bersifat khusus dan selalu diancamkan secara alternatif (Pasal 66 RKUHP). Pidana denda adalah sanksi yang bertujuan untuk mengembalikan keseimbangan agar ketertiban di dalam masyarakat pulih (I A Budijava dan Julianus Bandrio, 2010: 77). Namun masih pidana denda memiliki kelemahan di antaranya dengan adanya pilihan hukuman membayar denda atau kurungan. Banyak terpidana yang dihukum denda, lebih memilih menjalani hukuman kurungan. Mereka cenderung berpikiran lebihi enak menjalani hukuman kurungan beberapa bulan dari pada harus mengeluarkan uang dalam jumlah banyak. Dengan menjalani hukuman kurungan, seolah-olah hukuman denda itu sudah dibayar lunas oleh terpidana. Adanya penggantian hukuman tersebut sangat menguntungkan pelaku kejahatan, padahal sesungguhnya tujuan utama menjatuhkan hukum denda adalah untuk dibayar, 
bukan untuk diganti dengan hukuman lain. Pidana denda yang dijatuhkan pengadilan selama ini dapat dikatakan tidak efektif, karena sulit untuk dieksekusi dan tujuannya tidak tercapai sebagaimana yang diharapkan. hampir semua terpidana yang dijatuhi pidana denda, tidak bersedia atau tidak mau membayar denda tersebut. terpidana lebih memilih untuk menjalani hukuman kurungan pengganti. kelemahan perangkat hukum adalah tidak adanya upaya paksa bagi terpidana untuk melaksanakan hukuman denda. kelemahan ini tentu saja menguntungkan terpidana di satu pihak, namun merugikan negara di lain pihak. bagi terpidana tidak perlu mengeluarkan uang banyak untuk membayar denda, namun bagi negara kerugian yang ditimbulkan oleh perbuatan pelaku menjadi tidak dapat dipulihkan (Gatot Supramono, 2008: 35).

\section{Simpulan}

Pidana penjara sebagai salah satu pidana pokok, merupakan jenis pidana yang paling banyak diancamkan dalam KUHP Indonesia, begitu juga dalam RKUHP. Dalam pelaksanaan pidana penjara masih terdapat banyak kekurangan yang harus diperbaiki supaya pemidanaan yang dijatuhkan kepada pelaku kejahatan tidak menimbulkan efek negatif bagi pelaku dan keluarganya. Selain itu, pidana yang dijatuhkan kepada pelaku kejahatan harus sekaligus memperbaiki keadaan korban, keluarga korban, dan memulihkan keadaan masyarakat sesuai dengan perkembangan konsep pemidanaan ke arah restorative justice.

\section{Daftar Pustaka}

Andrew Stevano Kokong, Pidana Penjara Seumur Hidup dalam Sistem Pemidanaan, Lex Crimen, Vol. I, No. 2, Apr-Jun 2012.

Bagir Manan. 1999. Penelitian di Bidang Hukum. Jurnal Hukum Puslitbangkum, Nomor 1-1999, Lembaga Penelitian Univ. Padjadjaran.

Budijava, I A., dan Yulianus Bandrio, Eksistensi Pidana Denda di Dalam Penerapannya, Jurnal Hukum, Vol. XIX, No. 19, Oktober 2010.

Braithwaite, John, Setting Standards for Restorative Justice, Brit. J. Criminol, 42, 2002.

Damren, Samuel C., Restorative Justice Prison and the Native Sense of Justice, Journal of Legal Pluralism, nr. 47, 2002.

Dwidja Priyatno. 2009. Sistem Pelaksanaan Pidana Penjara di Indonesia, Bandung: Refika Aditama. 
Gatot Supramono. Hukuman Pidana Denda di Indonesia. Varia Pengadilan. No. 270. Mei 2008.

Gumboh, Esther, The Penalty of Life Imprisonment under International Criminal Law, African Human Rights Law Journal, 11, 2011.

Gumz Edward J., and Cynthia L. Grant, Restorative Justice: A Systematice review of the Social Work Literature, Families in Society, Volume 90, No. 1, 2009.

Ibnu Artadi, Menggugat Efektivitas Penerapan Pidana Penjara Pendek Menuju Suatu Proses Peradilan yang Humanis, Jurnal Hukum Pro Justitia, Oktober 2006, Volume 24 No. 4.

Liebling, Alison, Prison in Transition, International Journal of Law and Psychiatry, 29, 2006.

Otto Yudianto, Eksistensi Pidana Penjara dalam Perspektif Hukum Islam dan Hukum Adat (Kajian Pembaharuan Hukum Pidana), Jurnal Ilmu Hukum, Vol. 8 No. 15, Pebruari 2012.

Packer, Herbert L., The Limits of The Criminal Sanction, California: Stanford University Press, 1968.

Roy, Gargi, Is Capital Punishment Acceptable?, International Journal of Humanities and Social Science, Vol. 4 No. 2, Special Issue, January 2014.

Siti Nurjanah, Pidana dan Pemidanaan dalam Perundang-undangan di Indonesia, Jurnal Istinbath, Vol. 8, Nomor 2, November 2011.

Solomon, Okwendi Joseph, and Richard Nwankwoala, The Role of Restorative justice in Complementing the Jusstice System and Restoring Community Values in Nigeria, Asian Journal of Humanities and Social Sciencies (AJHSS), Volume 2, Issue-3, August 2014.

Suwarto, Pelaksanaan Pidana Penjara dengan Sistem Pemasyarakatan, Jurnal Hukum Pro Justitia, Volume 25 No. 2, April 2007.

Syahrizal Abbas, Mediasi dalam Hukum Syariah, Hukum Adat, dan Hukum Nasional, Jakarta: Kencana, 2011.

Umar al-Tamimi, Lembaga Pemafaan sebagai Alternatif Penyelesaian Perkara Pidana Perspektif Hukum Islam, Jurnal Diskursus Islam, Volume 1 Nomor 3, Desember 2013.

Kitab Undang-Undang Hukum Pidana

Rancangan Kitab Undang-Undang Hukum Pidana (Konsep 2012) 